\title{
Impact of Ethical Leadership on Project Success: Mediating role of Employee Trust and Moderating role of Ethical Orientation
}

\author{
Maha Matloob* \\ Capital University of Science and Technology, Islamabad, Pakistan
}

\begin{abstract}
This study examined the relationship between ethical leadership and project success with mediating role of employee trust and moderating role of ethical orientation. Data were collected from 100 employees from Kanji Advisory a project based company in Pakistan which designs and develops client responsive business strategies. The results proved that ethical leadership influences project success with the mediation of employee trust and with the moderation of ethical orientation.
\end{abstract}

\section{Introduction}

Following the famous corporate scandals (Enron, Worldcom, and Tyco), interest in ethical leadership has been intrigued; therefore more researches are being done in this domain after Enron scandal (Brown and Treviño, 2006). Ruiz-Palomino et al. (2011) argued that Ethical Leadership behavior spreads like a viral disease and creates an ethical work climate, where managers perform with honesty, employee trust their leaders and feel satisfied and committed to their jobs, which helps employees flourish in their jobs as well as increase organizations efficiency.

When employees have strong positive opinion about their leaders moral conduct and have the freedom to express their concerns, opinions and it leads to a strong sense of responsibility, satisfaction towards their job (Avey et al., 2011). Xu et al. (2016) explained that Ethical Leaders help organization in maintaining relationship based on trust with employees, which motivates employees to positively evaluate organization; this evaluation is based on the conduct of Ethical leader on the basis of which employees trust or refuse to trust organization. According to Brown et al. (2005), Ethical Leadership is linked with Social Learning Theory, as Ethical leaders shouldnt only impose ethical principles in an organization but they should be a model of a moral person. Leaders with extraordinary ethical behavior influence help in flourishing the creativity of subordinates (Chen and Hou, 2016).

Yang et al. (2016) explained that ethical leadership plays a vital role in increasing organizations and employees efficiency by helping supervisor to be an example of moral person, direct ethically and improve employee efficiency. Efficiency and creativity both are en-

*Corresponding author.

Email: mahadar1994@yahoo.com hanced when ethical leadership helps employees identify intrinsic value for job, rather than keeping an eye on external reward (Javed et al., 2017). Companies should select managers who reflect ethical leadership behavior while being employed, ones who can be an ethical role model and support ethical employees (Dinc and Nurovic, 2016).

In the current era, researchers are highly interested in the role of leadership in project success. There has been a research on Ethical Leadership for Virtual Project Teams, which suggests that Ethical Leadership of Virtual Project Teams not only improves organization efficiency but also employees job satisfaction and its one of the reasons for business success (Lee, 2009). A recent study suggests that further research should be conducted on the relationship between ethical leadership and Project success using different variables like intrinsic motivation, psychological safety, creative selfefficacy and trust in leadership as mediators (Javed et al., 2017). Working under ethical leadership, employees trust their organization to treat them with equality and value their concerns (Xu et al., 2016).

Lee-Kelley and Kin Leong (2003) found that perception of Project Manager regarding project success is influenced by his/her leadership style. A positive relation is found between project managers perception of project success and his personality, which shows that Project Managers strong belief on his/her leadership abilities plays a vital role in project success (Lee-Kelley and Kin Leong, 2003).To attain project success, ethical leaders need to promote employees trust by giving ethical orientation and being an example of ethical role model for employees. Trust is an important factor for stakeholders to achieve project success (Brinkhoff et al., 2015). 
Ethical Leadership could help employees develop trust towards their organization by providing an ethical orientation and by acting as a role model of ethical conduct and in result this will lead to project success. Our study contributes to ethical leadership literature in a way that it provides understanding about how ethical leadership can help achieve project success through employee trust. This study will help organizations in understanding how ethical leadership can help in achieving project success.

\section{Literature Review}

\subsection{Ethical leadership and project success}

Brown et al. (2005) explained ethical leadership as the demonstration of normatively appropriate conduct through personal actions and interpersonal relationships, and the promotion of such conduct to followers through two-way communication, reinforcement and decision making. Ethical leaders are the representatives of organizations ethical conduct and theyve to imitate for adherents to get their attention towards ethical message; they must be trustworthy, lawful and charismatic to be alleged as ethical leaders by being honest, being legitimate for employees rights and to influence ethics related outcomes (Brown et al., 2005). Ethical behavior can be seen in leaders when they are supporting something that is morally right and by doing so they are spreading awareness about ethical conduct and moral self-actualization (Zhu et al., 2004). Zhu et al. (2004) defined ethical leader as the one whose behavior is based on moral principles, one who is not focused on looking after his self-interest but concerned about subordinates rights, empowering employees for their growth and treat them fairly.

Project success is attained with the achievement of its targets relevant with the business objectives, product and services; whereas management success is achieved when budget, quality and control of the project related targets are achieved (Müller and Turner, 2010). Hussein et al. (2015) suggested that if projects are based on clear and realistic targets and on realistic criteria for success which helps in attaining top management and stakeholders trust; this can help lead to achieving project success. Ethical management of project teams results in improved production and distribution processes, increase in employee competence and satisfaction and present a leadership that can lead the project towards success (Lee, 2009). Geoghegan and Dulewicz (2008) posited that the aspect of leadership that deals with efficiently managing resources, empowering and motivating employees is found to have a positive relation with project success. Ethical leader is also characterized by these aspects. Mishra et al. (2011) suggested that project management is not only about completing project within time, budget and cost but practicing high level of moral character to get management and project team support which can help in achieving success. We therefore hypothesize that:

\section{H1. Ethical leadership is positively related to project suc-} cess.

\subsection{Mediating role of employee trust be- tween ethical leadership and project success}

Rousseau et al. (1998) defined trust as a psychological state comprising of the intention to accept vulnerability based upon positive expectations of the intentions or behaviors of another. McCauley and Kuhnert (1992) stated that employees continuously monitor organizations behavior towards them, i.e. if organizations management displays high level of trust in employees this will result in high level of employee trust on organization management. Through trust, employees develop a supportive behavior which helps in reducing conflict; develop a positive perception of employee towards leader, resulting in increased job satisfaction and efficiency (Gill, 2008). Employee trust in leader is his consent to be susceptible to the actions of his supervisor, whose responsibility is to convey top management orders and on whose actions employee does not have any control (Tan and Tan, 2000). Employees trust on leader increases if leaders words are followed by his actions (Wang and Hsieh, 2013). As Confucius said: People will hear what we say and observe what one does

Ethical leaders communicate to employees about what is expected from them in terms of ethics using two way communications; he listens to their ideas and asks them what is a right thing to do? (Brown et al., 2005). The distinctiveness of ethical leadership allows employees to gladly follow their employers actions and decision of their organization (Xu et al., 2016). When employees have a trusting relation with their leader they will communicate any bad conduct in organization with their supervisor without any fear (Payne, 2014). (Xu et al., 2016) study results suggested that employee trust is based on leaders ethical or unethical conduct, so for employees to trust organization, leader should be moral manager but most of all he should be a moral person. They argued that a positive relation exists between ethical leadership and employee performance because when managers are ethical leaders, their relationship with employee is based on trust and employees expect a fair treatment from organization.

Project managers adopt leadership behavior which can help in improving project performance, resulting in project success (Yang et al., 2011). Morris (1986) identified that success of a project is dependent upon real- 
istic and definite goal, resource availability, customer approval, and profitability, and competitive edge, completion of project according to plan and perceived value of project. Mazur et al. (2014) explained that in all phases of project from planning till implementation, top management support is the most critical factor for project success. Top management should keep in check the satisfaction and trust level of project manager towards organization because both are mandatory for project success in complex situations (Rezvani et al., 2016). Project success therefore can be achieved when employees trust their leader to provide them with unambiguous information and instructions for carrying out routine project activities and give them opportunity to reflect their views and ideas on management decisions. Trust is mandatory for successful completion of supply chain project; this success is influenced by supply chain partners relationship based on trust (Brinkhoff et al., 2015). Additionally, when employees trust their leader that he will empower them, treat them righteously and the leader will be an example of moral person then they go out of their way to perform project activities on time and on cost and communicate every problem with their leader, which helps in eradicating flaws in project and achieve project success. We therefore hypothesize that:

H2. Employee trust mediates positively between ethical leadership and project success.

\subsection{Moderating role of ethical orientation between ethical leadership and em- ployee trust}

Ethical orientation cannot be considered as dictatorial; it brings in cognitive processes needed to take an ultimate decision (Bigel, 2000). Webster and Trevino
(1995) argued that ethical orientation varies from person to person, it indicates towards individuals distinctive thinking and the way he counters different ethical dilemmas. They stated that the individuals are most likely to act according to their set standard decisions and according to what they think is right thing to do, they are least expected to cheat and when they see someone else involved in misconduct they are most likely to blow the whistle and they dont leave a chance to help others. Douglas et al. (2001) in their study showed a positive relation between ethical orientation and ethical judgments in intense moral circumstances. Ethical orientation consists of several orientations which are used by an individual to take a decision based on ethical principles; these orientations are justice, utilitarianism, responsibilities, self-interest and cultural recognition (Jones et al., 2003). Greenfield et al. (2008) stated that if individuals ethical orientation is based on relativity, there is a high chance of his involvement in earning management practices. Alder et al. (2008) on the basis of previous research suggested that though organizations operations effect employees ethical orientation but in reverse employees ethical orientation can affect his attitude towards organizations operations. On the contrary, if individuals ethical orientation is based on idealism, there is a low chance of his involvement in earning management behavior. Zweifel and Janus (2017) posited that medical doctors efficiency is dependent upon his ethical orientation, which means that if their ethical orientation is not strong they put minimum effort in taking care of patients.

Javed et al. (2017) stated that employees creativity is influenced by ethical leadership but in order to have that influence a manager needs to take on an ethical leadership style in which he emphasizes on organizations ethical values, justice environment and provides employees with the freedom to express their ideas, which can be utilized by organization. Chughtai et al.

Table 1: Bivariate Correlation

\begin{tabular}{|c|c|c|c|c|c|c|c|c|c|c|c|}
\hline & Variables & Mean & S.D & 1 & 2 & 3 & 4 & 5 & 6 & 7 & 8 \\
\hline 1 & Gender & 1.39 & 0.49021 & 1 & & & & & & & \\
\hline 2 & Age & 2.09 & 1.15553 & $.294^{* *}$ & 1 & & & & & & \\
\hline 3 & Qualification & 4.26 & 0.90587 & $.088^{* *}$ & $0.23^{* *}$ & 1 & & & & & \\
\hline 4 & Experience & 1.98 & 1.19747 & $.210^{* *}$ & $.921^{* *}$ & 0.033 & 1 & & & & \\
\hline 5 & Ethical Leadership & 3.915 & 0.56181 & $.286^{* *}$ & $.261^{* *}$ & $.097^{* *}$ & $.205^{*}$ & 1 & & & \\
\hline 6 & Employee Trust & 3.1733 & 0.97727 & $.241^{* *}$ & $.535^{* *}$ & $.196^{* *}$ & $.515^{* *}$ & 0.104 & 1 & & \\
\hline 7 & Prjct Success & 3.6764 & 0.59843 & 0.016 & 0.115 & 0.006 & 0.107 & $.489^{* *}$ & $.083^{* *}$ & 1 & \\
\hline 8 & Ethical Orientation & 3.9083 & 0.50523 & $.024^{* *}$ & 0.192 & 0.008 & 0.126 & $.313^{* *}$ & 0.045 & $.477^{* *}$ & 1 \\
\hline
\end{tabular}


(2015) stated that implementation of ethical leadership in organization can provide healthy work environment for employees. Nedkovski et al. (2017) study showed that leaders should promote organizations policies that help in the development and maintenance of generous and righteous Overseas Employment Corporation, which has a significant relation with employee and employer mutual trust. For an organizations policy and procedures development, ethical orientation can prove to be a base (Dickson et al., 2001). Employee who is working in an organization for a long period is aware of organizations ethics, rules, policies and values, he may respond to ethical leader in a more trustful manner as compared to employee who is not consistent with organizations principles (Walumbwa et al., 2011). Dinc and Nurovic (2016) suggested that organizations should spend more on ethical leaders training and their training should cover topics like conveying ethical orientation to employees, motivating employees who are involved in ethical conduct and be a role model of ethical conduct. If ethical leaders become an example of ethical role model and an ethical orientation is given regarding organizations ethical values and polices, this may help employees realize that they will be treated fairly and get a chance in decision making; this makes them trust the organization and ethical leader. We therefore hypothesize that:

H3. Ethical orientation moderates the relationship between ethical leadership and employee trust, such that ethical orientation strengthens the relationship.

\section{Theoretical framework}

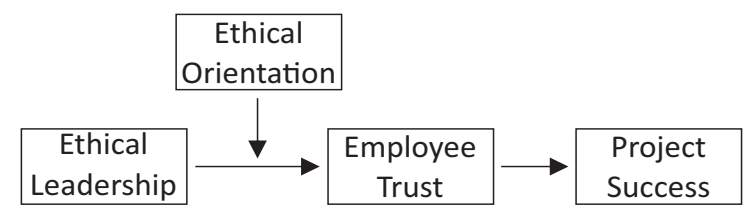

Figure 1: proposed model

\section{Methodology}

\subsection{Sample and Procedures}

Convenient sampling technique was used to study the impact of ethical leadership on project success with mediating role of employee trust and moderating role of ethical orientation. The sample was selected from private sector of Islamabad (Kanji Advisory). Kanji Advisory is a project based organization that designs and executes client responsive business strategies for private sector as well as civil society organizations to make rural area market segment more profitable. The purpose of selecting this company was because of its innovative business models and project plans made by the collaboration of civil and industrial society.

For research purpose, 120 questionnaires were distributed among employees, 105 questionnaires were returned back with full response, 6 questionnaires were incomplete and 9 were not returned. Majority of respondent were male $62 \%$ and female only $38 \%$. In age category, $40 \%$ were 18 to 25 years, $30 \%$ were in the range of $26-33,41 \%$ in the rage of $34-41,13 \%$ in the range of $42-49$ and $3 \%$ in the range of 50 and above years. In regards with qualification, $2 \%$ had Inter degree, 23\% attained bachelors degree, $24 \%$ had masters degree, $49 \%$ had MS/MPhil degree and $2 \%$ had PhD degree. With respect to the experience of employees, $46 \%$ had $0-5$ years of experience, $31 \%$ had $6-10$ years of experience, $7 \%$ in the category of $11-16$ years, $11 \%$ in the category of $17-22$ and $5 \%$ in the category of $23-28$ years of experience. Additionally, all respondents were assured that the collected information will only be used for academic purpose.

\subsection{Instruments}

\subsubsection{Ethical Leadership}

Ethical leadership scale developed by Brown and Treviño (2006) consists of 10 items. Sample items include Make fair and balance decisions and When making decisions, asks What is the right thing to do?. Same scale was used by Javed et al. (2017) and reported good reliability. Cronbach's Alpha was 0.876 .

\subsubsection{Project Success}

With respect to project success, respondents completed 14 item scales. Project success measurement standard tool are not available in published literature, and one tool which consists of previous research (??). Sample items include The outcomes of the project have directly benefited the intended end users, either through increasing efficiency or effectiveness and The project has made a visible positive impact on the target beneficiaries. Cronbach's Alpha was 0.914.

\subsubsection{Employee Trust}

With respect to employee trust respondents completed 3 items scale by (Mooradian et al., 2006). Sample items include I feel quite confident that the firm will always try to treat me fairly and Management at my firm is sincere in its attempts to meet the employees point of view. Cronbach's Alpha was 0.922.

\subsubsection{Ethical Orientation}

With respect to ethical orientation respondents completed 12 item scales by (Redfern and Crawford, 
2004). Sample items include People should make certain that their actions never intentionally harm another person, even to a small degree and Questions of what is ethical for everyone can never be resolved since what is moral or immoral is up to the individual. Five point Likert scale was used to measure all variables with descriptors like Strongly Disagree (1), Disagree (2), Neutral (3), Agree (4) and Strongly Agree (5). Cronbach's Alpha was 0.817.

\section{Results}

Table 3 shows the mediation result of employee trust on ethical leadership and project success relationship. Respondents completed the questionnaire and regression analysis on Hypothesis 1 Ethical leadership (EL) is linked with Project Success (PS) and it is also accepted, supported by the coefficient regression results $(\mathrm{B}=.871, \mathrm{p}<.01)$. Hypothesis 2 shows that $\mathrm{EL}$ is linked with Employee Trust (ET) and it is accepted as supported by the coefficient regression result $(B=1.049$, $\mathrm{p}<.01)$ and ET is linked with PS is also accepted, supported by the coefficient regression results $(\mathrm{B}=.779, \mathrm{p}$ $<.01)$. Furthermore, for hypothesis 2, mediation is run through Baron and Kenny (1986) four steps. EL and PS is regressed that shows the result $(\mathrm{B}=.871, \mathrm{p}<.01)$ then EL is regressed that shows result $(B=1.049, \mathrm{p}<$ $.01)$ then ET and PS are regressed that shows result (B $=.729, \mathrm{p}<.01)$, then in last step EL is regressed with PS with control mediator results shows significance (B $=.309, \mathrm{p}<.01$ ).

Table 4 shows that moderated regression analysis used for hypothesis 3 which states that ethical orientation plays a moderating role between Ethical Leadership and Employee Trust. Here, analysis of Baron and Kenny (1986) a three step regression analysis is done. In the first step, ET is regressed with PS (B $=.742, \mathrm{p}<$ $.01)$. In the second step, EO is regressed with EL along with controlling the effect of ET $(B=1.110, p<.01)$. In the last step, effect of ET is combined with EO then interaction term is formed and then this interaction term is regressed with PS. Result from regression analysis indicates $(\mathrm{B}=1.054, \mathrm{p}<.01)$ shows that $\mathrm{EO}$ is acting as a moderator.

\section{Discussion and Implication}

The purpose of this study was to show the effect of ethical leadership on project success and study the mediator mechanism of employee trust between ethical leadership and project success and an external effect of ethical orientation as moderator between ethical leadership and employee trust. The results showed significant relationship between ethical leadership and project success, employee trust was found to mediate the relationship between ethical leadership and project success and ethical orientation was found to moderate the relationship between ethical leadership and project success.

Above results are also supported by preceding study of Xu et al. (2016) their study result showed ethical leadership as a positive facilitator of employee trust in management. The significant relation between ethical leadership and project success shows that ethical conduct of a leader can enhance employee trust to communicate any issue or ideas with management which leads to decrease in project delay, over consumption of budget and directly lead to project success. Dinc and Nurovic (2016) suggested a positive relationship between ethical leadership and employee attitude. Particular project managers tend to adopt different leadership style for the improved performance of project, which the adoption of leadership style project team performance enhances and so does the project performance Yang et al. (2011).

Our study found that ethical orientation significantly influences the relation between ethical leadership and employee trust. Old employees as compared to new ones are more aware of the ethical orientations, rules and regulations and values of organization, which allows them to trust their ethical leader (Walumbwa et al., 2011). Such employees work hard to achieve the given targets because they are treated well by ethical leader by being given a right to share their views and report any problem faced by them which increases their trust on their leader because they feel honored.

This study confirmed the mediating role of employee trust between ethical leadership and project success and the relationship of ethical leadership and employee trust being moderated by ethical orientation. This helps in consideration of the fundamental mechanism of how ethical leadership effects project success. This study has important message for managers to adopt ethical leadership style to enhance the performance of project by being a moral person, promoting employees rights and empowering employees. Training should be conducted on how to adopt ethical leadership style in organizations.

\subsection{Limitations}

Our study contributes in the existing literature of leadership contribution in project success by collecting data from employees of project based organization for the accuracy of results. All hypotheses were proven with a significant relationship between all variables. This study results demonstrate that ethical leaders can help in achieving project success when employees trust leaders with the involvement of ethical orientation as 
Table 2: Regression Analysis Results

\begin{tabular}{lcccc}
\hline & \multicolumn{4}{c}{ Project Success } \\
Predictors & $\beta$ & $\mathbf{t}$ & $R^{2}$ & $\Delta R^{2}$ \\
\hline Ethical Leadership & 0.779 & 22.575 & 0.84 & 0.858 \\
\hline$p \leq .01$
\end{tabular}

Table 3: Mediated Regression Analysis

\begin{tabular}{|c|c|c|c|c|c|c|}
\hline \multirow[b]{2}{*}{ Predictor } & \multicolumn{3}{|c|}{ Employee Trust } & \multicolumn{3}{|c|}{ Project Success } \\
\hline & $\beta$ & $R^{2}$ & $\Delta R^{2}$ & $\beta$ & $R^{2}$ & $\Delta R^{2}$ \\
\hline \multicolumn{7}{|l|}{ Direct Effects } \\
\hline \multicolumn{7}{|l|}{ Step 1} \\
\hline Control Variables & & & & & 0.026 & \\
\hline \multicolumn{7}{|l|}{ Step 2} \\
\hline Ethical Leadership & $1.049^{* *}$ & 0.933 & 0.933 & $.837^{* *}$ & 0.871 & 0.869 \\
\hline \multicolumn{7}{|l|}{ Indirect Effects } \\
\hline \multicolumn{7}{|l|}{ Step 1} \\
\hline Control Variables & & & & & 0.026 & \\
\hline \multicolumn{7}{|l|}{ Step 2} \\
\hline Employee Trust & & & & $.829^{* *}$ & 0.855 & 0.884 \\
\hline \multicolumn{7}{|l|}{ Step 3} \\
\hline Ethical Leadership & & & & $.309^{* *}$ & 0.894 & 0.891 \\
\hline
\end{tabular}

Note: $N=100 .{ }^{*} p<.05 .{ }^{* *} p<.01,{ }^{* * *} p<.001$

Table 4: Moderated Regression Analysis

\begin{tabular}{lccc}
\hline & \multicolumn{3}{c}{ Employee Trust } \\
Predictor & $\beta$ & $R^{2}$ & $\Delta R^{2}$ \\
\hline Step 1 & & \\
Control Variables & & 0.26 & \\
Step 2 & & \\
Ethical leadership & 0.742 & 0.885 & 0.884 \\
Ethical Orientation & 1.11 & 0.915 & 0.913 \\
Step 3 & & & \\
EL*EO & 1.054 & 0.916 & 0.914 \\
\hline
\end{tabular}

Note: $N=100 .{ }^{*} p<.05,{ }^{* *} p<.01,{ }^{* * *} p<.001$

an external factor. Our study also has some limitation. The first limitation is that our sample size was small due to time limitation. If same size is large it will help in generalizing results. The second limitation is that we used employee trust as mediating variable while there are several other variables that can be used as mediator, e.g. intrinsic motivation and creativity.

\section{References}

Alder, G. S., Schminke, M., Noel, T. W., and Kuenzi, M. (2008). Employee reactions to internet monitoring: The moderating role of ethical orientation. Journal of Business Ethics, 80(3):481.

Avey, J. B., Palanski, M. E., and Walumbwa, F. O. (2011). 
When leadership goes unnoticed: The moderating role of follower self-esteem on the relationship between ethical leadership and follower behavior. Journal of Business Ethics, 98(4):573-582.

Baron, R. M. and Kenny, D. A. (1986). The moderatormediator variable distinction in social psychological research: Conceptual, strategic, and statistical considerations. Journal of personality and social psychology, 51(6):1173.

Bigel, K. S. (2000). The ethical orientation of financial planners who are engaged in investment activities: A comparison of united states practitioners based on professionalization and compensation sources. Journal of Business Ethics, 28(4):323-337.

Brinkhoff, A., Özer, Ö., and Sargut, G. (2015). All you need is trust? an examination of inter-organizational supply chain projects. Production and operations management, 24(2):181200.

Brown, M. E. and Treviño, L. K. (2006). Ethical leadership: A review and future directions. The leadership quarterly, 17(6):595-616.

Brown, M. E., Treviño, L. K., and Harrison, D. A. (2005). Ethical leadership: A social learning perspective for construct development and testing. Organizational behavior and human decision processes, 97(2):117-134.

Chen, A. S.-Y. and Hou, Y.-H. (2016). The effects of ethical leadership, voice behavior and climates for innovation on creativity: A moderated mediation examination. The Leadership Quarterly, 27(1):1-13.

Chughtai, A., Byrne, M., and Flood, B. (2015). Linking ethical leadership to employee well-being: The role of trust in supervisor. Journal of Business Ethics, 128(3):653-663.

Dickson, M. W., Smith, D. B., Grojean, M. W., and Ehrhart, M. (2001). An organizational climate regarding ethics: The outcome of leader values and the practices that reflect them. The Leadership Quarterly, 12(2):197-217.

Dinc, M. S. and Nurovic, E. (2016). The impact of ethical leadership on employee attitudes in manufacturing companies. Nile Journal of Business and Economics, 2(3):3-14.

Douglas, P. C., Davidson, R. A., and Schwartz, B. N. (2001). The effect of organizational culture and ethical orientation on accountants' ethical judgments. Journal of Business Ethics, 34(2):101-121.

Geoghegan, L. and Dulewicz, V. (2008). Do project managers' leadership competencies contribute to project success? Project Management Journal, 39(4):58-67.

Gill, S. (2008). Power and resistance in the new world order: fully revised and updated. Springer.

Greenfield, A., Norman, C. S., and Wier, B. (2008). The effect of ethical orientation and professional commitment on earnings management behavior. Journal of Business Ethics, 83(3):419-434.
Hussein, B. A., Ahmad, S. B., and Zidane, Y. J. (2015). Problems associated with defining project success. Procedia Computer Science, 64:940-947.

Javed, B., Naqvi, S. M. M. R., Khan, A. K., Arjoon, S., and Tayyeb, H. H. (2017). Impact of inclusive leadership on innovative work behavior: The role of psychological safety. Journal of Management $\mathcal{E}$ Organization, pages 1-20.

Jones, J., Massey, D. W., and Thorne, L. (2003). Auditors'ethical reasoning: Insights from past research and implications for the future. Journal of Accounting Literature, 22:45.

Lee, M. R. (2009). E-ethical leadership for virtual project teams. International Journal of Project Management, 27(5):456-463.

Lee-Kelley, L. and Kin Leong, L. (2003). Turner's fivefunctions of project-based management and situational leadership in it services projects. International Journal of Project Management, 21(8):583-591.

Mazur, A., Pisarski, A., Chang, A., and Ashkanasy, N. M. (2014). Rating defence major project success: The role of personal attributes and stakeholder relationships. International Journal of Project Management, 32(6):944-957.

McCauley, D. P. and Kuhnert, K. W. (1992). A theoretical review and empirical investigatiomn of employee trust in management. Public Administration Quarterly, pages 265284.

Mishra, P., Dangayach, G., and Mittal, M. (2011). An empirical study on identification of critical success factors in project based organizations. Global Business and Management Research: An International Journal, 3(3/4):356-368.

Mooradian, T., Renzl, B., and Matzler, K. (2006). Who trusts? personality, trust and knowledge sharing. Management learning, 37(4):523-540.

Morris, P. (1986). Research at oxford into the preconditions of success and failure in major projects.

Müller, R. and Turner, R. (2010). Leadership competency profiles of successful project managers. International Journal of Project Management, 28(5):437-448.

Nedkovski, V., Guerci, M., De Battisti, F., and Siletti, E. (2017). Organizational ethical climates and employee's trust in colleagues, the supervisor, and the organization. Journal of Business Research, 71:19-26.

Payne, H. J. (2014). Examining the relationship between trust in supervisor-employee relationships and workplace dissent expression. Communication Research Reports, 31(2):131140.

Redfern, K. and Crawford, J. (2004). An empirical investigation of the influence of modernisation on the moral judgements of managers in the peoples republic of china. Cross Cultural Management: An International Journal, 11(1):48-61. 
Rezvani, A., Chang, A., Wiewiora, A., Ashkanasy, N. M., Jordan, P. J., and Zolin, R. (2016). Manager emotional intelligence and project success: The mediating role of job satisfaction and trust. International Journal of Project Management, 34(7):1112-1122.

Rousseau, D. M., Sitkin, S. B., Burt, R. S., and Camerer, C. (1998). Not so different after all: A cross-discipline view of trust. Academy of management review, 23(3):393-404.

Ruiz-Palomino, P., Ruiz-Amaya, C., and Knörr, H. (2011). Employee organizational citizenship behaviour: The direct and indirect impact of ethical leadership. Canadian Journal of Administrative Sciences/Revue Canadienne des Sciences de l'Administration, 28(3):244-258.

Tan, H. H. and Tan, C. S. (2000). Toward the differentiation of trust in supervisor and trust in organization. Genetic, Social, and General Psychology Monographs, 126(2):241.

Walumbwa, F. O., Mayer, D. M., Wang, P., Wang, H., Workman, K., and Christensen, A. L. (2011). Linking ethical leadership to employee performance: The roles of leadermember exchange, self-efficacy, and organizational identification. Organizational Behavior and Human Decision Processes, 115(2):204-213.

Wang, D.-S. and Hsieh, C.-C. (2013). The effect of authentic leadership on employee trust and employee engagement. Social Behavior and Personality: an international journal, 41(4):613-624.
Webster, J. and Trevino, L. K. (1995). Rational and social theories as complementary explanations of communication media choices: Two policy-capturing studies. Academy of Management journal, 38(6):1544-1572.

Xu, A. J., Loi, R., and Ngo, H.-y. (2016). Ethical leadership behavior and employee justice perceptions: The mediating role of trust in organization. Journal of Business Ethics, 134(3):493-504.

Yang, C., Ding, C. G., and Lo, K. W. (2016). Ethical leadership and multidimensional organizational citizenship behaviors: The mediating effects of self-efficacy, respect, and leader-member exchange. Group $\mathcal{E}$ Organization Management, 41(3):343-374.

Yang, L.-R., Huang, C.-F., and Wu, K.-S. (2011). The association among project manager's leadership style, teamwork and project success. International journal of project management, 29(3):258-267.

Zhu, W., May, D. R., and Avolio, B. J. (2004). The impact of ethical leadership behavior on employee outcomes: The roles of psychological empowerment and authenticity. Journal of Leadership E Organizational Studies, 11(1):16-26.

Zweifel, P. and Janus, K. (2017). Medical ethics: enhanced or undermined by modes of payment? The European Journal of Health Economics, 18(1):119-129. 